\title{
HYBRIDITY IN POPULAR CULTURE: A TRANSNATIONAL ANALYSIS OF AMERICAN ADAPTATIONS OF JAPANESE MOVIES IN $21^{\text {st }}$ CENTURY
}

\author{
Della Putri Febrina \\ dellaputri_f@yahoo.com
}

\begin{abstract}
American popular culture has developed from time to time in producing the products. In the progress, the popular product has been modified to satisfy the taste of the consumer and Hollywood is being the one of popular product's makers which applies modifications in manufacturing movies; and the result of the development is hybridity seen in Hollywood movies.

This paper is written under American Studies discipline, by applying Transnational American Studies as the basis of the study. Furthermore, the research also used the theory of hybridity in constructing the analysis which concerned about American adaptations of Japanese original movies, namely The Grudge, Hachi: A Dog's Tale, and Godzilla. The method used in this paper is the qualitative research which comprises the library research by analyzing the three movies as the primary data and the information of the production as the secondary data.

As the result, there are some conclusions met in the analysis. The first conclusion is the three movies definitely adopt American and Japanese narratives and build a new sphere where the two nations living under the same frame. The adoption includes adoption of values, language, and iconic figure in Japan. The second conclusion relates with the changing of values and taste in Hollywood and shows that Hollywood has power in shifting the values of the original movies which is full of eastern values to be the ones which embodied American values. In short, it can be said that the three American adaptations studied in this paper triggers the emergence of American movies with Asian narratives.
\end{abstract}

Keywords: Hybridity, transnational, popular culture, adaptation

\section{Introduction}

America popular culture is famous across the world. There are music, fashion, movies, books, and many more types of American products which gain any followers and consumers around the world. Fiske mentioned in Understanding Popular Culture that "to be made into popular culture, a commodity must also bear the interests of the people” (Fiske,
1989, p.23). Thus, it is apparent to say that in American popular culture gains its reputation because American is succeeded in producing popular products. Some apparent examples may be taken from the growth of chain fast food restaurant such as McDonalds, Pizza Hut, and KFC. The following American fast food restaurants are successful in gaining many consumers in the world and it triggers the opening of 
many branches in many parts of the world. Hence, there is particular phenomenon can relate with the branches of those fast food restaurant, especially in relation with the branches outside American. The fact that these branches also adapt to the local culture to create menus that can satisfy the costumers and that fact is eventually brought some impacts in the development of the American chain fast food restaurant. One of obvious impact is the variety of menu in each branch of American chain fast food restaurant.

Forni in Chaucer's Afterlife: Adaptations in Recent Popular Culture explained about the concept of adaptation that "adaptation is never simply imitation but necessarily requires an interpretation of the prior work in order to make the text relevant, comprehensible, and appealing to new audiences” (Forni, 2013, p.23). Later on, the mechanism is supported by the need of producer to meet the expectations from the audience and how taste influences this kind of method as later also mentioned by Kraidy,

In this environment program-format adaptations and co-productions are increasingly common; the former entails the adaptation to local parameters of tastes and style of a popular program format gleaned from a different culture, whereas the latter involve a partnership between several companies based in multiple countries (Kraidy, 2005, p.101).

The statement puts hybridity and adaptation in the similar position as the two concepts which works together to face the globalization in the $21^{\text {st }}$ century. Hence, the practice of American products in adapting and hybridizing becomes the starting point of the paper in analyzing how American alters the taste and value of popular culture product which has different values.

In this study, the writer uses American adaptations of Japanese movies because it is interesting to see the change that can be happened in the adaptations. It is clear that American and Japanese have different values and taste in presenting the culture. Yet, the phenomenon of adaptation between American and Japanese movies has been doubled around 1990s until present. It was started with the invasion of Japanese Horror in America, which begins with the Ringu, Ju-on, Rinne, Uzumaki, Noroi, and so on. The hype is strong in America that the Hollywood urges to adapt the movies and makes the American version of those movies. It gives birth to The Ring, The Grudge, One Missed Call, and Pulse which are known as American version of Japanese Horror 
movies. However, this paper will not only focus one genre of movie, but also other genres movies, namely Science Fiction and Melodrama. It is important step for finding the contributions of the two genres in some adaptations such as Shall We Dance, Hachiko, The Edge of Tomorrow, and many others. As a result, this paper chooses three adaptation movies with different genre as the objects of the study, namely The Grudge, Hachi: A Dog's Tale, and the 2014's Godzilla. The considerations in choosing these three movies are because these three movies are heavily depicted the three iconic figures in Japan which was Onryou, Hachiko, and Godzilla and the fact that the three movies gains huge impression in America.

Starting with the adaptation named The Grudge, the movie can be considered as crucial moment in Japanese adaptation movies. Compared with the other two, the sales can be considered as the smallest, which is only \$325,680 (boxofficemojo.com). However, the movie sets a franchise in America adaptations and has another interesting fact, namely The Grudge is remade by same director of the original movie, Takashi Shimizu. Meanwhile, the second object, Hachi: A Dog's Tale is adapted from Hachiko Monogatari which was released in 1987.
This story of the loyalty dog is eventually based on the real dog in Japan which receives much recognition among Japanese. The dog is also the symbol of faithfulness in Japan society as the figure is immortalized in Shibuya station and there are many stories about Hachiko written in the book such as Turner's Hachiko: the True Story of a Loyal Dog, Newman's Hachiko Waits, and Wroblewski's The Story of Edgar Sawtelle. The last movie is Godzilla, which eventually has been adapted into American version in 1956 by the name of Godzilla, King of Monsters! and being remade for the second time under the same name in 1998. The movie that is used as the object of the movie is eventually the third installment of Godzilla adaptations. Basically, it is vital to put this movie in study because the movie has a huge success in America. It reaches a bigger profit than the 1956's Godzilla and 1998's Godzilla as it hit $\$ 200,676,069$ for the domestic sales and \$328,400,000 for foreign sales (boxofficemojo.com). In correlation with the three movies, the writer wants to analyze if the practice of adapting and hybridizing undergone in the American chain fast food restaurant also happened in the American adaptations of Japanese movies. Hence, it is worthy to 
see if the hybridity seen in the three movies has constructed a new system of adapting movies in Hollywood. It is because American and Japanese have different values, compared with the other genuine American movies which mirror American values or the adaptations that come from European countries.

Generally, the paper aims to analyze American adaptations regarding to the change of taste and value in Hollywood. The writer argues that the American adaptations of original Japanese movies have changed values beneath the original Japanese movies. Thus, the movie can be appropriate to be presented with American audience. In the same time, the adaptation brings the emergence of hybridity in American popular movies. Also, the adaptation of Japanese movies triggers a question if the taste of Hollywood begins to take interest in eastern value as Hollywood have made some American adaptations of Japanese movies, such as The Grudge, Hachi: A Dog's Tale, and Godzilla which are the objects of the study.

\section{Methodology}

This paper applies a descriptive qualitative approach which focuses on gathering the data related to the topic, but the data is only in the descriptive manner, with no numerical involvement. As Creswell (2003) stated that,

Qualitative research is a form of interpretive inquiry in which researchers make an interpretation of what they see, hear, and understand. Their interpretations cannot be separated from their own backgrounds, history, contexts, and prior understandings. After a research report is issued, the readers make an interpretation as well as the participants, offering yet other interpretations of the study (p. 212).

Therefore, the research is done by the interpretation of the writer in analyzing the research and how the collection of data enriches the understanding of the writer in conducting further studies about transnational perspective in American popular culture that related to American adaptations of Japanese movies in $21^{\text {st }}$ century. As the primary data of the paper is three movies which are adaptations of Japanese movies, namely The Grudge, Hachi: A Dog's Tale, and Godzilla, the data involves the close reading about each movie and the production process of the movie. Along with that, the secondary data is needed to complete the information about the nature of movie adaptations in Hollywood, the hybridity that is around American movies and the reception of the 
audience toward adaptation movies. There is also information of other movie adaptations which is derived from other countries outside Japan. These data and information are collected from close book text reading, articles, journals, and the reliable websites in the Internet.

Also, the research is related to Transnational Studies which correlates the theory of hybridity, especially in relation with American adaptations of Japanese movies, namely The Grudge, Hachi: A Dogs Tale, and Godzilla.

\section{Discussion}

First object, The Grudge, is an American horror movie produced in 2004 and it is adapted from Ju-On which created in 2002. Ju-On is a Japanese movie which is actually based on a novel with a same title by Ohishi Kei. Thus, it is proper to say that The Grudge is an indirect adaptation of the novel because the previous adaptation, $\mathrm{Ju}-\mathrm{On}$, is based on a novel. The Grudge, precisely, is about an American social worker named Karen Davis who encounters onryou (spirit) which haunts a house and enrage the people who come and live in the house. From this occurrence, the writer finds that Hollywood deliberately changes the main character's nationality into American, albeit the main character in the novel and original movie are Japanese. By seeing the changing of character, the writer finds that Hollywood purposely changes the character to emphasize that The Grudge is the production of Hollywood, even though the onryou is remained in the movie as the 'villain'.

Regarding to the concept built by Hollywood, the writer finds that the concept reflects the statement of Rosaldo in Same Other: Negotiating African Identity in Cultural Production that,

Hybridity can imply a space betwixt and between two zones of purity in a manner that follows biological usage that distinguishes two discrete species and the hybrid pseudospecies that results from their combination. Similarly, the anthropological concept of syncretism asserts, for example, that folk Catholicism occupies a hybrid site midway between the purity of Catholicism and that of indigenous religion (Rosaldo via Palmberg and Maria, 2001, p. 14).

The Grudge constructs an interaction between America which is represented by the prominence of Karen Davis, the protagonist in the movie and Japanese which is encoded by the presence of onryou as the opponent of Karen in the movie. It creates a communication 
between two different identities. However, the writer argues if the movie shapes a new identity as described by Rosaldo in his statement about folk Catholicism since the writer can still identify the difference between these two characters, Karen Davis is an American and the onryou is the ghostly character from Japan. Furthermore, the occurrence is rather close to Friedman's statement about 'intermingling of differences' (Friedman, 1998, p.84) which keeps the differences between the two characters and later, the differences are being blurred in the merging between the two characters. The portrayal of this kind of hybridity can be seen in The Grudge and is heavily depicted by the development of the character of Karen Davis.

Regarding the examples mirrored by Karen Davis as the main character in The Grudge, the writer can also relates them with the concept of mimicry and the 'Other'. Bhabha argues that "the process of mimicry leads to hybrid cultures as an ongoing process of colonial imposition and resistance from the colonized" (Jackson, 2011, p.113) in which Karen Davis, as the main character, portrays an individual that mimicked the local culture to mingle with the local culture, namely Japanese culture. In here, the writer assumes the hybridity in the The Grudge emerged because of the process of mimicry where the main character is described as an American character who adapts with her new environment by studying the local culture and trying to imitate the manner of Japanese people. However, the notion is not completely worked in every scene. One of the examples is Karen behaves differently while she is witnessing a crying baby in the train. She's pitying the mother while everyone in the train consider it as a bother in public. It's an obvious thing in Japan that letting a baby in public area is a bother because it is considered as a violation to other people's privacy. In the same time, it tells that she does not completely absorb Japanese's way of as an American, albeit she is trying to learn the local culture. The writer sees the scene as the depiction of the 'Other' in the movie. The 'Other' is also a concept proposed by Bhabha and he explains that the concept is derived from a notion of "otherness that is insistently identified with the vagaries of the depolitized Eurocentric critic" (Bhabha, 1994, p. 19). The concept initially relates to the idea of the West and the rest where the West is valued as the superior. Yet, in The Grudge, as the movie is a product of adaptation from Japanese movie, the writer sees that the 'Other' is 
depicted by the presence of American character, albeit The Grudge is a product of American production. However, the function of 'the Other' in The Grudge is seen as important asset as the movie often relies on portraying the condition of the 'Other' in the movie.

Regarding the idea of the 'Other' that presumed previously, the writer continues the discussion about The Grudge in the perspective of the 'Other' in the movie. In the discussion, the writer presents the evidences from the scenes which show how the American characters are intended to be the important aspects, despite the environment of the story happened in Japan and the core of the story is heavily related with the Japanese folk story about onryou. Plate and Jasper also states in Imag(in)ing Otherness: Film Visions of Living Together (AAR Cultural Criticism Series) that, "The term "otherness" is initially used here to denote that which resides outside the margins of the dominant culture representations, outside the social-symbolic order" (Plate and Jasper, 1999, p.4). In the process, The Grudge strengthens its eminence as an American movie, albeit the idea is derived from a Japanese movie entitled Ju-On.

Generally, from the portrayal of the American characters in the above discussion, the writer finds that there is a correlation of hybridity and the notion of the 'Other'. The American characters in the movie is aimed as the 'Other' which are identified differently with the local people, Japanese. Yet, the existence of American characters as the 'Other' seems to deploy the status of The Grudge as an American adaptations because it can be seen in the way the scenes employed the characteristics of American and Japanese. In fact, The Grudge is a horror movie that employs the idea of onryou as the villain in the story. As the movie has a clear relation with this evil spirit from Japan, the movie puts a subtle impression about the life of the Japanese and the value beneath the movie. Also, there is a clear mixture between American and Japanese characters as there are American and Japanese characters appeared in the movie. In portraying the characters, the writer also finds some American characters imitates the local culture, albeit there is a slight hint of 'Otherness' seen in the movie which emphasizes how the American characters are different with the Japanese characters. The mixture of language is also seen in The Grudge where some American characters are capable of speaking in Japanese and vice versa. Moreover, the adoption of onryou describes the hybridity 
in the movie where The Grudge borrows, not only the plot of the story from $\mathrm{Ju}-\mathrm{On}$, but also the character of onryou in the movie.

Then, the second movie is Hachi: A Dog's Tale which released in 2009. As previously mentioned, the movie is adapted from a Japanese movie entitled Hachiko Monogatari which also based on the real story of a dog named Hachi. In contrast with The Grudge, the movie is directed by a Swedish director named Lasse Hallstrőm and the casts are almost all American actors and actresses with some minor Japanese actors. The movie itself is British-American production albeit it portrays about the story of loyalty dog in Japan and the important thing is the movie regarded as the American version of Hachiko Monogatari. While the plot remains in the same way, the story is built in American environment.

Then, to see the hybridity of the movie clearly the writer examines the scenes displayed in the movie which portrays the cultures between American and Japanese. The first scene is begun with the scene of elementary grade schoolers talk about the heroes of their lives in front of the class. The first girl, Heather, mentions Columbus as the hero in her life. Everyone is clapping their hands after she ends the speech about her admiration about Colombus. Next, when a boy named Ronnie writes 'Hachiko' in the blackboard, everyone is frowning and none of them understands about the figure of Hachiko. In this scene, the atmosphere of 'Other' is employed as Hachiko is unknown by Ronnie's classmates. Slightly different with The Grudge, the 'Other' in the movie is Hachiko, the iconic figure of the movie. In relation with the finding, the writer quotes Rieser, Fuchs, and Phillips' statement about iconic figure in America,

Icons are American icons not because they are limited to the nation, but because they create the nation state as an imagined community through the myth of an 'America' that is presented as a stable, indisputable term-historically (a genealogy that implicitly runs from 1607), geographically (delimited by national borders), and culturally (anchored in a supposed unity of cultural values). Thus, the American iconic figures are defined by the fact that they are adopted or accepted by a large segment of the national public, but, more importantly, in that they play a decisive role in the shaping of national discourses (Rieser, Fuchs, and Phillips, 2013, p.6).

Hachiko in the movie is the 'Other', nobody know about Hachiko. Even, Ronnie, who mentions Hachiko, does not 
know for sure about Hachiko's origin. He only knows that Hachiko is his grandfather's dog.

Then, the movie continues and eventually shows that Hachiko is a dog from Japan and above of all, it is owned by a monk, before it is sent away to somewhere in America. The writer finds that the movie, somehow, gives an implied notion that Hachi: A Dog's Tale is an American adaptation of Japanese movie by transporting Hachiko, the iconic figure from the original movie, to America. Moreover, the movie highlights the relation between Hachiko and the monk as both of them are from Japan and how this relationship, later, is used to create the atmosphere of Zen in the movie. Zen is from Eastern and as proposed by Humphreys in his A Western Approach to Zen, he explains that Zen teaches people that the intellectuality is eventually limited and thinking beyond the thinking is the only way to reach the Truth and to gain the experience of knowing mind (Humphreys, 1999, p. 15). Hachiko’s action by sitting and waiting for its late owner can be compared with the action that is usually done by the monk in meditating because both actions do not require anything, except to sit and focus into one purpose. In the movie, the purpose is achieved as the director shows that Hachiko eventually meets his late owner again.

Initially, Hollywood also produced some movies about dogs and one of the well-known movies was Lasssie Come Home which portrays the story of a rough collie that reaches thousand miles only to come back to its true owner. The movie is a hit and Lassie becomes a symbol of friendship between a dog and its owner. The movie also inspires some other movies about dog which eventually highlights the bond between the owner and the dog, such as Air Bud, Beethoven, Old Yeller, Far from Home: The Adventures of Yellow Dog, and many more. Inevitably, the American movies about dog are always the story of a young boy who has a dog and how he creates a friendship with his dog. Because of that, dog is known as a man's best friend in America and that very idea is a bit different with the value that has been implemented in Hachi: A Dog's Tale. There were several characteristics of Hachi that has been explained in the story regarding his identity as a dog derived from Japan.

Generally, the hybridity in the movie is also employed similarly with The Grudge, albeit the setting of the movie is not in Japan, but in Woonsocket, Rhode Island. Hachiko's story is imported into 
America and there is no change of the depiction of the dog, except the movie gives a subtle notion that the story is happened in America. The character of Hachiko is not changed into another 'Beethoven' or another 'Lassie', the movie keeps its identity as a Japanese dog and at the same time, the idea brings a new concept in American dog's movie because the identity and value of the dog are derived from Japan.

The last movie is Godzilla in 2014. The figure is famous among Americans. West in The Japanification of Children's Popular Culture: From Godzilla to Miyazaki states that the Americans takes interest in Japanese popular culture begins since Godzilla was put in the screen in Japan in 1954 and in America in 1956. The following movie about Godzilla is soon released and the American children are familiarized with Godzilla as same as the Japanese youngsters” (West, 2008, p. vii).

As American production, Godzilla which directed by Gareth Edwards, puts some implied notion that the American characters in the movie have close relation with Japanese culture. One of the scenes is when a young Ford Brody is planning to make a surprise birthday for his father. Among his toys, there are some American toys such as American toys soldiers, tanks, helicopters, a miniature of Godzilla, a miniature of US rocket, and a huge poster of Godzilla which is written in Kanji. The depiction of the scene constructs an idea that this American movie is heavily related with Japan. In comparison with the previous installation, 1998's Godzilla cuts any relation between the movie and the original movie. Robert Emmerich, as the director of the movie, makes an American adaptation that completely removes the ties between Godzilla and the origin. Instead of showing the connection between Japan and America as it appears in 1954's Gojira and 1956's Godzilla, the movie is made the connection with French as the story of Godzilla in 1998 indicates that the appearance of Godzilla is caused by the French government.

Earlier, the writer has mentioned that the story develops its plot around the event that happened in a nuclear company in Japan. The portrayal of the story eventually depicts the Fukushima earthquake of 2011. The earthquake had many casualties and one of the events that gained much attention during that time is when there was a release of nuclear material that caused by the earthquake. Gareth Edwards, as the director of the movie, mentions his intention to put the event in the movie, 
Our film is not about Fukushima at all, and the reactor is located in a fictional city near Tokyo," says Edwards, "but I wanted it to reflect the questions that the incident at Fukushima raised. The news images from the Tohoku earthquake are burned onto our minds. Other generations had the Titanic or the Blitz. For us it's tsunamis and September 11. "So when you make a disaster movie that is trying to say something about our world, you reach for images that haunt you." (Edwards via Collin, 2014, telegraph.co.uk).

Regardless the fact that the movie is the American version of Gojira, the director intentionally puts one of the significant accidents that ever happened in Japan. However, since the story is the American version, the involvement of America in the story is inevitable. The plot progresses into a point that harmful creature named MUTO went to Nevada, Texas to take away the nuclear disposal in there. In the movie, the American armed forces were heavily participated in managing the attack to MUTO and there was no any other party that cooperated with American in destroying MUTO, except Godzilla. From this depiction, the writer assumes the intention of the director to focus on the American armed forces and Godzilla is the metaphor of the collaboration between
America and Japan. The collaboration go even further when Godzilla was the one managed to destroy MUTO and one of the American characters named Ford Brody was the one who destroy the MUTO's eggs. Some of the characters in 2014's Godzilla perform code switching. In the movie, there is a portrayal of American family who lived in Japan. Unlike Ben's family in The Grudge, the family of Joe Brody in Godzilla has stayed in Japan for a long time and it is usual that the characters in the family were capable of speaking Japanese.

In sum, after extracting how the cultural hybridity is presented in the three movies, the writer have assumes that regardless the different genre of the movie, all the three movies makes clear boundary between the two cultural identities which surfaced in the movies. There is no truly blending culture in the movies as the writer can see on how the American and Japanese character carried out their culture in their own manners, even though there are some hints that some characters tried to mimic the other culture. Commonly, the three movies also put the Japanese narratives in the plot while the movies are executed favorably in Hollywood's way. The dramatization, the big explosion, and the terror which were put in those three 
movies resembles the way of Hollywood produced the movie. However, the alienated cultural epitomes that had been shown by the iconic figure of onryou, Hachiko, and Godzilla fabricate the three movies into movies which surfaced American and Japanese storylines. The code switching is also important to be noticed in these three movies as the code switching has a significant implication to make the Japanese iconic figures keeps their identities as Japanese as the characters in the three movies which perform the code switching functioned as the bridge which shadows the American and Japanese cultures in the movies.

The hybridity is much related with the idea of adaptation in which the writer finds the adaptation is the reason why the emergence of hybridity seen in the three movies. Referring to the notion, the writer puts the consideration that the hybridity in these movies relates with its status as popular product. Crothers in Globalization and American Popular Culture mentions that,

The primary purpose of popular culture was to be consumed by users who paid for the privilege of reading a mass-produced book or magazine. Such production was essentially secular in nature, meaning that nothing was sacred or holy- everything was available for marketing and consumption (Crothers, 2007, p.13).

While the writer agrees that the presence of the movies is heavily related with the desire of the producer for getting much audience, the writer argues that the movies in thesis are secular in nature. All three movies carry identities of American and Japanese to create the adaptation movies and identity is important as stated by Weedon that, "identity is important to occupying the position of 'knowing subject' and it is as knowing subjects that we speak and act most effectively in the world” (Weedon, 2004, p. 154). Furthermore, the presence of the double identities in the movie creates hybridity in the three movies. The hybridity is seen through the adoption of characters, language, formula, and plot in the movie, creating the American adaptations of Japanese movies.

To relate these movies and the taste of the movie production in Hollywood, it is important for the writer to mention the significance of the taste. In The Sociology of Taste, Gronow (1997) explains about the taste's importance of Pierre Bourdieu that,

Bourdieu adopted one possible empiricist solution to the antimony 
of taste by claiming that the taste of the ruling class is always the legitimate taste of a society. But in his opinion this legitimate class is not genuine good taste: in fact, there could not possibly be any genuine good taste. Legitimate taste pretends to be the universally valid and disinterested good taste, whereas in reality it is nothing more than the taste of one particular class, the ruling class (p. 11).

Regarding to above statement, Bourdieu points out the taste usually relates with the ruling class. However, the writer argues if the taste in Hollywood's production related to the ruling class. In fact, Hollywood has extensive history in producing movies. There are tons of movies being produced from time to time and that is the reason why Hollywood can be regarded as one of the most productive movie industries in the world. Yet, by producing many movies, it means there is a possibility that Hollywood tries to employ the similar formula to achieve the demand in manufacturing movies and that is eventually the result of the hyperproducing movies in Hollywood. The producer tends to apply similar formula to make shortcuts in producing movies. The example can be seen in the fascination of the producer with composing slasher theme in creating horror movies and the method is being reproduced from time to time by the expectation that the audience will favor the movie because it is the same as the well-known previous one. Langford (2005) mentions about the constant production of series in horror movies in Film Genre (Hollywood and Beyond) that,

Horror films in general remain sensational, gory, and relatively cheap, and are promoted in ways that discourage 'serious' critical attention. The seriality and repetition to which horror properties are prone (Halloween, five installments since 1978; Friday $13^{\text {th }}$, nine since 1980; Nightmare on Elm Street, seven from 1984 to 1994, plus parodic franchise 'face-off' Freddy vs Jason, 2003; even knowing postmodern pastiches Scream, 1996, Scary Movie and I Know What You Did Last Summer, 1997, generating their own part-parodic but seriously profitable franchises) also render horror 'generic' in the old, pejorative sense of term (p. 160).

Some movies mentioned above produces some iconic figures such as Ghostface, Leatherface, Freddy Krueger, Michael Myers, Jason Voorhees, and many more. All of them engage with the insanity of outcast characters that drives the characters into killing machines. The other example that can be taken in projecting the similar horror movies villains is its ties 
with demon-themed plot. Since Rosemary's Baby, The Exorcist and The Omen regain much recognition among American audience, the horror movies set with the demon as the antagonist become the common plot. For The Omen, the movie built its franchise and manufactured several sequels and a remake such as Damien: Omen II, Omen III: The Final Conflict, Omen IV: The Awakening, and 2006's the Omen.

Then, in the 2000s, the trend of Asian horror boomed all over the world, along with the arrival of Japanese Horror to America. Hantke (2010) in American Horror Film (The Genre at the Turn of the Millenium) frames about the beginning of Hollywood's fascination toward Asian films,

Roy Lee, the so-called remake king whom Variety identifies as "the man who brought Asia's horror film culture to America," has been the engine driving this trend (Frater). He has brokered the sale of rights to remake numerous Asian films to American producers, earning himself and his company, Vertigo Entertainment, producer credits in the process (Friend). Lee began the process with J-Horror films in the early 2000s, with remakes of Ringu (1998) (remade as The Ring in 2002), Ju-on (2003) (remade as The Grudge in 2004), and Dark Water
(2002) (remade with the same title in 2005) (p.5).

Roy Lee, as told in the above statement, is the one who opened the gate of Asian movies, particularly Japanese horror movies. This concept transforms the idea about the ghost in American movies which, earlier, does not bear any identity, unless for some horror movies which based on Native Americans' myth and legend such as The Shining and Poltergeist. Nonetheless, the movies do not clearly imprint the cultural identity in in the movies as much as The Grudge. For instance, The Shining does not clearly depict the appearance of Native American as the spirit which haunted the protagonist in The Shining. Instead the director just gives some implied hints about the connection of the movie with Native American by the putting Native Americans' artworks in the movie. Nonetheless, the appearance of onryou in American horror movies provides an invention in American horror movies' characters that the 'monster' in the movie can possess characteristics that make it identifiable.

Japanese culture which is exploited in the movie adaptation functions as the attraction to American audience and the 
Japanese culture are considered as the magnet that brings an interest in the audience because the movies are carried different values. It is an American movie that the audiences know, but there is an enigma about the movie because there is an alien culture that is different with the American value. This notion is slightly related with the hypothesis that is being assumed by Joseph and Fink in Performing Hybridity that "the hybridity might result a recolonizing multiculturalism which functioned as a tool to homogenize the complexity of cultural identities and historical specificity of narratives of origin” (Joseph and Fink, 1999, p. 250). In the production of the three movies, the complexity of the cultural identities of the characters brings hybridity in the movies as the movies does not focus entirely with America and its values, as there are other characters that obviously come from Japan. Related to that, the hybridity rejuvenates the familiar notion in Hollywood's method of producing movies. The cultural identity of Japan that is displayed in the three movies had added new insight of American movies that the American movies are no longer about America and Americans; it can be about another nation and implants new values that are completely different with the American values.

In addition, the appearance of the three movies as adaptation movies maps the timeline of American adaptation of Japanese movies. The Grudge which is produced in 2004 initiates the emergence of adaptation of Asian horror movies such as Dark Water (2005), Pulse (2006), One Missed Call (2008), The Eye (2008), The Echo (2008) and many more; Hachi: A Dog's Tale is the continuation of Hollywood's adaptation of Japanese drama such as Shall We Dance which had similar actor, namely Richard Gere; and Godzilla (2014) prolongs the franchise of the monster's movie in Hollywood. Moreover, the writer finds that the adaptation adds some spice on Hollywood's fascination toward Asian narratives, especially Japanese, as Hollywood begins to produce more movies which are heavily related with Japanese culture, such as The Last Samurai (2003), Memoirs of A Geisha (2005), Letters From Iwo Jima (2006), The Ramen Girl (2008), Emperor (2012), Unbroken (2014), The Forest (2016), and many more.

Lev in Transforming the Screen, 1950-1959 mentions that during World War II, England becomes the important consumer of Hollywood movies and then 
the sales of the movies becomes even greater by the supporting of Western Europe, Latin America, and Japan in consuming the movies since in the early 1960s (Lev, 2003, p.147). Essentially, Nachbar and Lause mentioned in Popular Culture: An Introductory Text that,

The need and desire of the producers of popular culture to reflect audience beliefs and values in order to ensure that their product will be accepted by the masses, and the uncertainty involved in defining the precise nature of this zeitgeist at any particular time (Nachbar and Lause,1992, p.6).

Therefore, from the above statement, the writer finds that the fascination of Hollywood in producing movies with eastern value can be related with the status of Hollywood as a global market and its desire to fulfill the audience's expectation.

\section{Conclusion}

The three adaptation movies taken as the objects of the study in the thesis have shown hybridity in textual and production perspectives. The mixture of elements that reflected in the movie implies that American adaptations have dual identities which replicate the American and Japanese elements. In the same time, there are also some adoptions of Japanese value seen in the movies which indicates that the American adaptations of original Japanese movies in the $21^{\text {st }}$ century tends to put the Japanese value in American sphere, as seen in The Grudge, Hachi: A Dog's Tale, and Godzilla. The values in the three movies can be strongly interpreted as the Japanese culture depicted clearly in the three movies by putting the three iconic figures from Japan in the three movies. The Grudge replicates onryouwhich came from Japanese folktale about avenging ghost, Hachi: A Dog's Tale put the story and the portrayal of Hachiko, a loyal dog from Japan, and Godzilla forms a story about the tall monster from Japan.

However, there is a clear distinction between the three American adaptations and the original movies which put the American adaptations as the product of Hollywood. The Grudge describes the story of onryou based on American characters' perspectives, Hachi: A Dog's Tale defines the story of Hachiko as a loyal dog seen in the perspective of the American people, and Godzilla which trails the story of a monster in the defending the American people from unknown threat. While the American adaptations clearly put the three iconic figures from Japan, the story within the movies are about American narratives. The 
iconic figures of the three movies are adopted in the three movies to see the building of the story which relate to American people.

The domination of the American characters in the movie gives clear identities that the movies are American productions. The intention of Hollywood to put the American characters as the main characters in the three movies indicates Hollywood's need to make the three movies to identify the characteristic of American. From the emergence, the writer also sees Hollywood's intention to get the similar portion of popularity that once had been had by the original movies, albeit the original movies represent Asian narratives. The Grudge that once was known as JuOn, a Japanese horror movie is labeled as an American movie, despite the plot is mostly similar with the original one; so do the two other movies, Hachi: A Dog's Tale and Godzilla.

Also, the American adaptations of Japanese movies that bring familiarity to American audience toward Japanese values also trigger the production of movies which related to Asian narratives. The Grudge which tells about an Asian horror made some producers in America to make some adaptations of Asian horror movies and in the same, the production of the Asian horror movies in American sphere establishes the power of Hollywood in creating J-Horror in American environment; Hachi: A Dog's Tale enriches American narratives about dogs which later inspires some popular American products in depicting the loyalty of Hachiko; and Godzilla which previously had been known by American audiences had stabilized the connection of American toward the Japanese iconic figure as Godzilla is no longer seen as a threat for American, but as the hero that maintained the life of Americans.

\section{References}

Bhabha, H. K.(1994). The Location of Culture. New York: Routledge.

Creswell, J. W. (2003). Research Design: Qualitative, Quantitative, and Mixed Method Approaches, Second Edition. California: SAGE Publications, Ltd.

Crothers, L. (2007). Globalization and American Popular Culture. Maryland: Rowman \& Littlefield Publishers.

Fiske, J. (1989). Understanding Popular Culture. London: Routledge.

Forni, K. (2013). Chaucer's Afterlife: Adaptations in Recent Popular Culture. Jefferson: McFarland.

Friedman, S. (1998). Mappings: Feminism and the Cultural Geographics of Encounter. Princeton: Princeton University Press.

Gronow, J. (1997). The Sociology of Taste. New York: Routledge. 
Hantke, S. (2010). American Horror Film (The Genre at the Turn of the Millenium). Mississippi: University of Mississippi Press.

Joseph, M., \& Fink, J. N. (1999). Performing Hybridity. Minnesota: University of Minnesota Press.

Kraidy, M. M. (2005). Hybridity, of the Culture Logic of Globalization. Philadelphia: Temple University Press.

Langford, B. (2005). Film Genre (Hollywood and Beyond). Edinburgh: Edinburgh University Press, Ltd.

Nachbar, J., \& Lause, K. (1992). Popular Culture: An Introductory Text. Bowling Green: Bowling Green State University Popular Press.

Palmberg, M., \& Baaz, M. E. (2001). Same and Other: Negotiating African Identity in Cultural Production. Uppsala: Nordic African Institute.

Plate, S. B., \& Jasper, D. (1999). Imag(in)ing Otherness: Filmic Visions of Living Together (AAR Cultural Criticism Series). Oxford: Oxford University Press.

Rieser, K., Fuchs, M., \& Phillips, M. (2013). ConFiguring America: Iconic Figures, Visuality, and the American
Identity. Chicago: University of Chicago Press.

Turow, J. (2013). Media Today: Mass Communication in a Converging World. London: Routledge.

Collin, R. (2014, May 13). Gareth Edwards interview: 'I wanted Godzilla to reflect the questions raised by Fukushima'. Retrieved May 23, 2016, from The Telegraph: http://www.telegraph.co.uk/culture/fil $\mathrm{m} / 10820543 /$ Gareth-Edwardsinterview-I-wanted-Godzilla-toreflect-the-questions-raised-byFukushima.html

Edwards, G. (Director). (2014). Godzilla [Motion Picture].

Hallström, L. (Director). (2009). Hachi: A Dog's Tale [Motion Picture].

Mojo, B. O. (n.d.). Godzilla (2014). Retrieved January 6, 2016, from Box Office Mojo: http://www.boxofficemojo.com/movie s/?id=godzilla2012.htm

Mojo, B. O. (n.d.). Ju-On: The Grudge. Retrieved May 15, 2016, from Box Office Mojo: http://www.boxofficemojo.com/movie s/?page=intl\&id=juonthegrudge.htm 